\title{
NARKOBA, BAHAYA DAN CARA MENGANTISIPASINYA
}

\author{
Ahmad Darwis, Gabena Indrayani Dalimunthe, Sulaiman Riadi \\ Dosen UMN Al Washliyah Fak Ekonomi \\ Ahmad_darwis2001@yahoo.com
}

\begin{abstract}
Abstrak
Penyalahgunaan narkoba di kalangan pemuda dan remaja tidak dapat dipungkiri teernyata masih banyak yang mengkonsumsinya di lingkungan sekitar kita. Dampaknya bagi kesehatan dan masa depan tidaklah sedikit. Bahaya narkoba bagi pecandu dan kalangan muda, para pelajar sangat banyak dan jika tidak segera dihentikan kebiasaan mengkonsumsi narkoba maka hal ini akan memperburuk derajat kesehatan penggunanya itu sendiri secara pelan pelan tapi pasti serta akan merusak masa depan kehidupan mereka. Dalam kehidupan bermasyarakat para pemuda atau pelajar membutuhkan suasana lingkungan yang kondusif dan nyaman dari penyalahgunaan narkoba, oleh karena itu penanggulangan narkoba menjadi tanggung jawab bersama dimulai dari keluaraga, kemudian masyarakat dan pemerintah. Melalui kegiatan pengabdian ini diharapkan mampu memberikan pemahaman kepada masyarakat di kabupaten karo tentang bahaya yangdiderita akibat penyalahgunaan narkoba, jenis jenis dan macam-macam narkotika serta bagaimana cara menanggulanginya. Metode yangdigunakan dalam menanggulangi narkoba adalah memberikan presentasi pemahaman yang benar tentang narkoba serta adanya diskusi tanya jawab seputar jenis jenis narkoba, bahayanya dan langkah langkah yang efektif agar masyarakat di Kabupaten Karo dapat menanggulanginya terlebih dahulu harus dimulai dari pribadi masing-masing keluarga, kemudian masyarakat dan pemerintah.
\end{abstract}

Kata kunci : Narkoba, Bahaya, Antisipasi.

\begin{abstract}
Drug abuse among youth and adolescents can not be denied there are still many who consume them in the environment around us. The impact on health and the future is not small. The dangers of drugs for addicts and young people, the students are very much and if not immediately discontinued the habit of consuming drugs then this will worsen the health degree of users themselves slowly but surely and will damage the future of their lives.. In the life of the youth or the students need a conducive and comfortable environment atmosphere from drug abuse, therefore the prevention of drugs becomes a joint responsibility starting from the family, then the community and the government. Through this devotional activity is expected to provide understanding to the community in karo district about the dangers suffered due to drug abuse, types and types of narcotics and how to overcome them. The methods used in tackling drugs are giving a correct understanding of the narcotics and the discussion about the types of drugs, the danger and the effective steps that people in Karo Regency can overcome first must start from the personal of each family, then the community and government.
\end{abstract}

Keywords: Drugs, Hazards, Anticipation. 


\section{PENDAHULUAN}

Dewasa ini banyak ditemukan kasus-kasus Narkoba, menghinggapi para generasi muda, mulai dari tingkat artis, penegak hukum, hingga masyarakat umum.Padahal, narkoba sangat berbahaya bagi generasi penerus.Bahaya narkoba tersebut karena berhubungan dengan efek ketagihan atau kecanduaan, yang dalam istilah kedokteran disebut Addiction Effect.

Menurut UU No.22 Tahun 1997 tentang Narkotika disebutkan pengertian Narkotika adalah "zat atau obat yang berasal dari tanaman atau bukan tanaman baik sintetis maupun semi sintetis yang dapat menyebabkan penurunan atau perubahan kesadaran, hilangnya rasa, mengurangi sampai menghilangkan rasa nyeri, dan dapat menimbulkan ketergantungan".

Sebenarnya Narkoba itu obat legal yang digukan dalam dunia kedokteran, namun dewasa ini Narkoba banyak disalahgunakan.Bahkan kalangan muda tidak sedikit yang menggunakan narkoba.Banyak dari mereka yang menggunakan Narkoba dengan alasan untuk kesenangan batin, namun sayangnya tidak banyak yang mengetahuai bahaya narkoba.

Sebenarnya Narkoba itu obat legal yang digukan dalam dunia kedokteran, namun dewasa ini Narkoba banyak disalahgunakan.Bahkan kalangan muda tidak sedikit yang menggunakan narkoba.Banyak dari mereka yang menggunakan Narkoba dengan alasan untuk kesenangan batin, namun sayangnya tidak banyak yang mengetahuai bahaya narkoba.

Narkotika bekerja dengan mengikat reseptor di otak dan memblokir rasa sakit.Sehingga, obat ini bekerja dengan baik untuk menghilangkan rasa sakit dalam jangka pendek.Namun, narkotik ini dapat memberikan efek ketagihan.Kecanduan narkoba ditunjukkan oleh penderita, yang tidak dapat mengontrol penggunaan narkoba secara terus menerus.Kecanduan narkoba dapat menimbulkan keinginan kuat untuk senantiasa menggunakan obat.

Hingga kini penyebaran narkoba sudah hampir tak bisa dicegah.Mengingat hampir seluruh penduduk dunia dapat dengan mudah mendapat narkoba dari oknum-oknum yang tidak bertanggung jawab. Misalnya saja dari bandar narkoba yang senang mencari mangsa didaerah sekolah, diskotik, tempat pelacuran, dan tempattempat perkumpulan genk. Tentu saja hal ini bisa membuat para orang tua, ormas, pemerintah khawatir akan penyebaran narkoba yang begitu meraja rela. Upaya pemberantas narkoba pun sudah sering dilakukan, namun masih sedikit kemungkinan untuk menghindarkan narkoba dari kalangan remaja maupun dewasa, bahkan anakanak usia SD dan SMP pun banyak yang terjerumus narkoba. Hingga saat ini upaya yang paling efektif untuk mencegah penyalahgunaan Narkoba pada anak-anak yaitu dari pendidikan keluarga.Orang tua diharapkan dapat mengawasi dan mendidik anaknya untuk selalu menjauhi Narkoba.Hingga kini penyebaran narkoba sudah hampir tak bisa dicegah.Mengingat hampir seluruh penduduk dunia dapat dengan mudah mendapat narkoba dari oknum-oknum yang tidak bertanggung jawab. Misalnya saja dari bandar narkoba yang senang mencari mangsa didaerah sekolah, diskotik, tempat pelacuran, dan tempattempat perkumpulan genk. Tentu saja hal ini bisa membuat para orang tua, ormas, pemerintah khawatir akan penyebaran narkoba yang begitu meraja 
rela. Upaya pemberantas narkoba pun sudah sering dilakukan, namun masih sedikit kemungkinan untuk menghindarkan narkoba dari kalangan remaja maupun dewasa, bahkan anakanak usia SD dan SMP pun banyak yang terjerumus narkoba. Hingga saat ini upaya yang paling efektif untuk mencegah penyalahgunaan Narkoba pada anak-anak yaitu dari pendidikan keluarga. Orang tua diharapkan dapat mengawasi dan mendidik anaknya untuk selalu menjauhi Narkoba

\section{METODE PELAKSANAAN}

Metode

pelaksanaan kegiatanpengabdian masyarakat yang dilaksanakan di desa Merdeka Kabupaten Karo desa Merdeka Kabupaten Karo adalah:

1. Pembentukan pola penanggulanganNarkoba secara terpadu bagi masyarakatsalah satu pemukiman yangberada di sekitar lingkungan desa Merdeka Kabupaten Karo yang sebagian warganya adalah pelajar, mahasiswa, pegawai dan pengguna jasa perguruantinggi baik secara langsung maupun

tidak langsung

2. Sebagai dampak konsentrasi pendidikan, Desa Merdeka Kabupaten Karo adalah merupakan pemukiman masyarakat petani, daerahnya subur dan udaranya dingin, serta tingkat pendidikan masyarakat di lingkungan desa tersebut relatif rendah dan jauh dari lembaga Pendidikan.

3. Rencana kegiatan penanggulan narkoba adalah memberikan pemahaman kepada individu, rumah tangga, masyarakat, pemerintah yang ada di Kecamatan. Dengan Kegiatan yang dilakukan:

a. Sosialisasi memberikan presentasi pemahaman yang benar tentang Narkoba, Jenis jenis Narkoba, Bahaya terhadap kesehatan dan Masa depan serta upaya upaya yang dilakukan untuk dapat mengantisipasinya yang dimulai dari diri/keluarga,Masyarakat, Pemerintah.

b. Metode yang digunakan ceramah dengan menggunakan Slide, OHP, Diskusi, dan Tanya Jawab.

\section{HASIL DAN PEMBAHASAN}

\section{Pengertian dan Jenis Narkoba}

a. Pengertian Narkoba

Narkoba merupakan singkatan dari (Narkotika, Psikotropika dan Bahan Adiktif lainnya).Terminologi narkoba familiar digunakan oleh aparat penegak hukum seperti polisi (termasuk didalamnya Badan Narkotika Nasional), jaksa, hakim dan petugas Pemasyarakatan. Selain narkoba, sebutan lain yang menunjuk pada ketiga zat tersebut adalah Napza yaitu Narkotika, Psikotropika dan Zat Adiktif. Istilah napza biasanya lebih banyak dipakai oleh para praktisi kesehatan dan rehabilitasi. Akan tetapi pada intinya pemaknaan dari kedua istilah tersebut tetap merujuk pada tiga jenis zat yang sama.

Menurut UU No.22 Tahun 1997 tentang Narkotika disebutkan pengertian dari:

Narkotika adalah "zat atau obat yang berasal dari tanaman atau bukan tanaman baik sintetis maupun semi sintetis yang dapat menyebabkan penurunan atau perubahan kesadaran, hilangnya rasa, mengurangi sampai menghilangkan rasa nyeri, dan dapat menimbulkan ketergantungan”.

Psikotropika adalah "zat atau obat, baik alamiah maupun sintetis bukan narkotika, yang berkhasiat psikoaktif melalui pengaruh selektif pada susunan saraf pusat yang 
menyebabkan perubahan khas pada aktivitas mental dan perilaku".

Bahan adiktif lainnya adalah "zat atau bahan lain bukan narkotika dan psikotropika yang berpengaruh pada kerja otak dan dapat menimbulkan ketergantungan.

Menurut pakar kesehatan narkoba sebenarnya adalah psikotropika yang biasa dipakai untuk membius pasien saat hendak dioparasi atau obatobatan untuk penyakit tertentu.Namun kini presepsi itu disalah gunakan akibat pemakaian yang telah di luar batas dosis.

Narkotika adalah setiap senyawa psikoaktif dengan sifat yang menginduksi sistem saraf pusat. Misalnya: morfin, heroin dan turunannya, seperti xanax. Dari sudut pandang farmakologi, narkotika digunakan hanya untuk menghilangkan rasa sakit yang parah. Ketika digunakan dengan hati-hati dan di bawah perawatan langsung dokter, obat ini dapat efektif dalam mengurangi rasa sakit.

Narkoba adalah zat kimia yang dapat mengubah keadaan psikologi seperti perasaan, pikiran, suasana hati serta perilaku jika masuk ke dalam tubuh manusia baik dengan cara dimakan, diminum, dihirup, suntik, intravena, dan lain sebagainya.

Narkoba dapat digolongkan menjadi 3 (tiga) golongan, yaitu :

a. Narkotika - untuk menurunkan kesadaran atau rasa.

b. Psikotropika - mempengaruhi psikis dari pengaruh selektif susunan syaraf pusat otak

c. Obat atau zat berbahaya

\section{Jenis-jenis Narkoba}

Yang merupakan Jenis-jenis Narkoba ialah :

1. Opiatatau Opium (candu) : Merupakan golongan Narkotika alami yang sering digunakan dengan cara dihisap (inhalasi).

2.Morfin : Merupakan zat aktif (narkotika) yang diperoleh dari candu melalui pengolahan secara kimia. Umumnya candu mengandung 10\% morfin. Cara pemakaiannya disuntik di bawah kulit, ke dalam otot atau pembuluh darah (intravena)

3. Heroin : Merupakan golongan narkotika semisintetis yang dihasilkan atas pengolahan morfin secara kimiawi melalui 4 tahapan sehingga diperoleh heroin paling murni berkadar $80 \%$ hingga $99 \%$. Heroin murni berbentuk bubuk putih sedangkan heroin tidak murni berwarna putih keabuan (street heroin).Zat ini sangat mudah menembus otak sehingga bereaksi lebih kuat dari pada morfin itu sendiri. Umumnya digunakan dengan cara disuntik atau dihisap. Timbul rasa kesibukan yang sangat cepat/rushing sensastion $( \pm 30-60$ detik) diikuti rasa menyenangkan seperti mimpi yang penuh kedamaian dan kepuasan atau ketenangan hati (euforia).Ingin selalu menyendiri untuk menikmatinya.

4.Ganja : Berasal dari tanaman kanabis sativa dan kanabis indica. Pada tanaman ini terkandung 3 zat utama yaitu tetrahidrokanabinol, kanabinol dan kanabidiol. Cara penggunaannya dihisap dengan cara dipadatkan menyerupai rokok atau dengan menggunakan pipa rokok.

5. LSD atau lysergic acid atau acid, trips, tabs : Termasuk sebagai golongan halusinogen (membuat khayalan) yang biasa diperoleh dalam bentuk kertas berukuran kotak kecil sebesar 1/4 perangko dalam banyak warna dan gambar. Ada juga yang berbentuk pil atau kapsul. Cara menggunakannya dengan meletakkan LSD pada permukaan lidah dan bereaksi setelah 
30-60 menit kemudian dan berakhir setelah 8-12 jam.

6. Kokain : Mempunyai 2 bentuk yakni bentuk asam (kokain hidroklorida) dan bentuk basa (free base). Kokain asam berupa kristal putih, rasa sedikit pahit dan lebih mudah larut dibanding bentuk basa bebas yang tidak berbau dan rasanya pahit. Nama jalanan kadang disebut koka, coke, happy dust, snow, charlie, srepet, salju, putih. Disalahgunakan dengan cara menghirup yaitu membagi setumpuk kokain menjadi beberapa bagian berbaris lurus di atas permukaan kaca dan benda yang mempunyai permukaan datar. Kemudian dihirup dengan menggunakan penyedot atau gulungan kertas. Cara lain adalah dibakar bersama tembakau yang sering disebut cocopuff. Menghirup kokain berisiko luka pada sekitar lubang hidung bagian dalam.

\section{Bahaya Narkoba}

A. Bahaya yang ditimbulkan akibat memakai Narkoba Menurut Efeknya:

1.Halusinogen, efek dari narkoba ini bisa mengakibatkan bila dikonsumsi dalam sekian dosis tertentu dapat mengakibatkan seseorang menjadi berhalusinasi dengan melihat suatu hal/benda yang sebenarnya tidak ada / tidak nyata contohnya kokain \& LSD

2.Stimulan, efek dari narkoba ini bisa mengakibatkan kerja organ tubuh seperti jantung dan otak bekerja lebih cepat dari kerja biasanya sehingga mengakibatkan seseorang lebih bertenaga untuk sementara waktu, dan cenderung membuat seorang pengguna lebih senang dan gembira untuk sementara waktu

3.Depresan, efek dari narkoba ini bisa menekan sistem syaraf pusat dan mengurangi aktivitas fungsional tubuh, sehingga pemakai merasa tenang bahkan bisa membuat pemakai tidur dan tidak sadarkan diri. Contohnya putaw
4.Adiktif, Seseorang yang sudah mengkonsumsi narkoba biasanya akan ingin dan ingin lagi karena zat tertentu dalam narkoba mengakibatkan seseorang cenderung bersifat pasif , karena secara tidak langsung narkoba memutuskan syaraf-syaraf dalam otak,contohnya ganja , heroin , putaw .

"Jika terlalu lama dan sudah ketergantungan narkoba maka lambat laun organ dalam tubuh akan rusak dan jika sudah melebihi takaran maka pengguna itu akan overdosis dan akhirnya kematian".

\section{B. Bahaya yang ditimbulkan akibat memakai narkoba menurut jenisnya : \\ 1. Opiat atau Opium (candu)}

-Menimbulkan rasa kesibukan (rushing sensation)

-Menimbulkan semangat

-Merasa waktu berjalan lambat.

-Pusing, kehilangan keseimbangan/mabuk.

-Merasa rangsang birahi meningkat (hambatan seksual hilang).

-Timbul masalah kulit di sekitar mulut dan hidung.

\section{Morfin}

-Menimbulkan euforia.

-Mual, muntah, sulit buang hajat besar (konstipasi).

-Kebingungan (konfusi).

-Berkeringat.

-Dapat menyebabkan pingsan, jantung berdebar-debar.

-Gelisah dan perubahan suasana hati.

-Mulut kering dan warna muka berubah.

3. Heroin

-Denyut nadi melambat.

-Tekanan darah menurun.

-Otot-otot menjadi lemas/relaks.

-Diafragma mata (pupil) mengecil (pin point). 
-Mengurangi bahkan menghilangkan kepercayaan diri.

-Membentuk dunia sendiri (dissosial) : tidak bersahabat.

-Penyimpangan perilaku : berbohong, menipu, mencuri, kriminal.

-Ketergantungan dapat terjadi dalam beberapa hari.

-Efek samping timbul kesulitan dorongan seksual, kesulitan membuang hajat besar, jantung berdebar-debar, kemerahan dan gatal di sekitar hidung, timbul gangguan kebiasaan tidur.

-Jika sudah toleransi, semakin mudah depresi dan marah sedangkan efek euforia semakin ringan atau singkat

\section{Ganja}

-Denyut jantung atau nadi lebih cepat.

-Mulut dan tenggorokan kering.

-Merasa lebih santai, banyak bicara dan bergembira.

-Sulit mengingat sesuatu kejadian.

-Kesulitan kinerja yang membutuhkan konsentrasi, reaksi yang cepat dan koordinasi.

-Kadang-kadang menjadi agresif bahkan kekerasan.

-Bilamana pemakaian dihentikan dapat diikuti dengan sakit kepala, mual yang berkepanjangan, rasa letih/capek.

-Gangguan kebiasaan tidur.

-Sensitif dan gelisah.

-Berkeringat.

-Berfantasi.

-Selera makan bertambah.

\section{LSD atau lysergic acid atau acid,} trips, tabs

-Timbul rasa yang disebut Tripping yaitu seperti halusinasi tempat, warna dan waktu.

-Biasanya halusinasi ini digabung menjadi satu hingga timbul obsesi terhadap yang dirasakan dan ingin hanyut di dalamnya.

-Menjadi sangat indah atau bahkan menyeramkan dan lama kelamaan membuat perasaan khawatir yang berlebihan (paranoid).

-Denyut jantung dan tekanan darah meningkat.

-Diafragma mata melebar dan demam.

-Disorientasi.

-Depresi.

-Pusing

-Panik dan rasa takut berlebihan.

-Flashback (mengingat masa lalu) selama beberapa minggu atau bulan kemudian.

-Gangguan persepsi seperti merasa kurus atau kehilangan berat badan.

\section{Kokain}

-Menimbulkan keriangan, kegembiraan yang berlebihan (ecstasy).

-Hasutan (agitasi), kegelisahan, kewaspadaan dan dorongan seks.

-Penggunaan jangka panjang mengurangi berat badan.

-Timbul masalah kulit.

-Kejang-kejang, kesulitan bernafas.

-Sering mengeluarkan dahak atau lendir.

-Merokok kokain merusak paru (emfisema).

-Memperlambat pencernaan dan menutupi selera makan.

-Paranoid.

-Merasa seperti ada kutu yang merambat di atas kulit (cocaine bugs).

-Gangguan penglihatan (snow light).

-Kebingungan (konfusi).

-Bicara seperti menelan (slurred speech).

Dampak negatif penyalahgunaan narkoba terhadap anak atau remaja bisa juga di lihat dari sikap dan prilakunya sebagai berikut:

- Perubahan dalam sikap, perangai dan kepribadian,

- Sering membolos, menurunnya kedisiplinan dan nilai-nilai pelajaran,

- Menjadi mudah tersinggung dan cepat marah,

- Sering menguap, mengantuk, dan malas, 
- Tidak memedulikan kesehatan diri,

- Suka mencuri untuk membeli narkoba

\section{Cara mengantisipasi Bahaya Narkoba.}

\section{a. Dari dalam diri sendiri}

1. Mencintai dan mensyukuri hidup sebagai anugrah Yang Maha Kuasa.

2. Temu-kenali dan kembangkan daya, minat, bakat, serta hobbi dirimu.Setiap orang mempunyai kelebihan dan kekurangan pada diri masing-masing, temu-kenali kelebihan dan kekurangan tersebut pada dirimu, kembangkan hal yang positif pada dirimu dan sadari serta tinggalkan hal yang negatif dari dirimu.

3. Setiap orang mempunyai masalah dalam hidupnya. Hadapi dan pecahkan masalah itu, bukan hindari, apalagi dengan melarikan diri kepada penyalahgunaan narkoba Penyalahgunaan narkoba bukan penyelesaian masalah tetapi memperparah masalah.

.4.Komitmen. Komitmen merupakan cara paling ampuh dalam mencegah pengaruh dari teman untuk mengkonsumsi narkoba. Selama kita berkomitmen untuk tidak menggunakan narkoba insya Allah kita akan terhindar dari yang namanya Narkoba.

5. Fokuslah Pada tujuan dalam menjalani segala sesuatu hendaknya fokus pada tujuan walaupun rintangan menghadang. Seperti halnya pada Narkoba kalau kita memikirkan mengapa teman- teman mengajak saya untuk mengkonsumsi narkoba (fokus pada masalah) maka masalah tersebut yang akan menghampiri kita namun bila kita berfikir bagaimana agar teman-teman tidak mempengaruhi saya untuk mengkonsumsi narkoba (fokus pada tujuan) maka pasti ada jalan yang bias dilalui untuk mengatasi masalah tersebut. So jangan pikirkan masalah tapi tujuan.

6. Katakanlah "tidak" Bila kita diajak oleh teman untuk mengkonsumsi Narkoba maka katakanlah "tidak" dan kalau masih memaksa katakan "Saya masih sayang sama tubuh saya" dan bila teman anda memang berwatak keras/pemaksa, maka pergilah darinya dan jangan temui dia untuk sementara waktu. harus memperkuat kepercayaan diri dan keberanian kamu untuk mengatakan tidak serta menolak ajakan teman untuk menyalahgunakan narkoba dan perbuatan lainnya yang melanggar agama, hukum, atau moral.

7. Pandai-pandailah memilih teman. Bertemanlah dengan teman yang dapat dipercaya. Karena teman yang dapat dipercaya tidak akan menjerumuskan kita ke dalam dunia Narkoba.

\section{b. Dari pihak lain}

1. Peran Orang Tua, Orang tua perlu memantau perkembangan anak, bias dengan berkumpul, berbincang-bincangpalingn tidak 15 menit tiap hari. Dengan berbincangbincang

maka orang tua dapat mengetahui perkembangan anaknya. . Ingatkan bahwa Narkoba akan merusak kerja otak, susunan syaraf pusat, merusak ginjal, lever dan sebagainya. Lebih baik mencegah putra-putri kita terkena pengaruh Narkoba daripada kita harus mengobatinya. Karena untuk proses pengobatan dan penyembuhan tidaklah mudah dan membutuhkan biaya yang tidak sedikit

2. Motivasi dari teman sebaya Teman yang baik adalah teman yang mau memberi 
kepada kita. Dengan motivasi dari teman kita, kita akan merasa nyaman untuk bergaul dan tentunya akan terhindar dari bahaya narkoba.

3. Lingkungan Tempat tinggal dimana kita tinggal disitu kita juga akan mendapatkan

pembelajaran baik yang bersifat positif maupun bersifat negative, semua itu tergantung dengan kondisi lingkungan dimana kita tinggal. Jangan salah pilih tempat tinggal Jangan pernah mencobanya,walaupun untuk iseng atau untuk alasan lain, kecuali perintah dokter/alasan medis.Pilihlah pergaulan yang aman jangan yang berbahaya.Pilih kegiatan yang sehat, tak merugikan diri sendiri ataupun orang lain, ikutilah klub olah raga, organisasi sosial. Lakukan hobi bersama teman dan keluarga.Gunakan waktu dan tempat yang aman, jangan keluyuran malammalam.Bersantailah dengan keluarga, berkaraoke, piknik, makan bersama, masak bersama, beres-beres bersama nonton bersama keluarga.Penciptaan lingkungan keluarga yang sehat, harmonis, komunikatif, terbuka, penuh perhatian dan kasih sayang upaya pencegahan penyalahgunaan narkoba.

4. Pencegahan penyalahgunaan narkoba dilakukan di dalam keluarga, sekolah, komunitas, tempat kerja, dan masyarakat luas, melalui kegiatan komunikasi, informasi dan edukasi dengan menggunakan berbagai media (antar pribadi,massa cetak atau elektronik). Program pencegahan ditunjukan kepada pengembangan positif dan tanggung jawab terhadap diri, keluarga dan masyarakat; pengembangan kemampuan pemecahan masalah (problem coping capacity).Pendidikan keterampilan hidup; pendidikan keorang-tuaan, pendidikan hidup sehat.
5. Untuk masyarakat Indonesia yang majemuk diperlukan metoda, teknik media serta pesan komunikasi yang bervariasi untuk masing-masng masyarakat , etnis, budaya, kelompok usia, tingkat pendidikan serta tingkat sosial ekonomi.

6.Demikian pula penciptaan lingkungan sekolah. lingkungan kerja dan lingkungan sosial yang sehat dan harmonis, adalah penting untuk mencegah penyalahgunaan narkoba. Dalam hubungan ini peran, kepedulian, tangung jawab:guru, Kepala Sekolah, pimpinan perusahaan tokoh masyarakat dan tokoh agama juga sangat penting.

7.Hindarilah kebiasaan merokok .Hasil penelitian menunjukan bhawa merokok dan meminum minuman beralkohol merupakan pintu pembuka ke penyalahgunaan narkoba. Bila sudah terlanjur merokok, segera tinggalkan kebiasaan merokok. Niscaya dirimu akan lebih sehat, lebih segar dan bugar serta lebih bersemangat tanpa merokok.

Ada tiga tingkat intervensi yang dapat dilakukan pemerintah, yaitu:

1.Primer, sebelum penyalahgunaan terjadi, biasanya dalam bentuk pendidikan, penyebaran informasi mengenai bahaya narkoba, pendekatan melalui keluarga, dll. Instansi pemerintah, seperti halnya BKKBN, lebih banyak berperan pada tahap intervensi ini.kegiatan dilakukan seputar pemberian informasi melalui berbagai bentuk materi KIE yang ditujukan kepada remaja langsung dan keluarga.

2.Sekunder, pada saat penggunaan sudah terjadi dan diperlukan upaya penyembuhan (treatment). Fase ini meliputi: Fase penerimaan awal (initialintake)antara $1-3$ hari dengan melakukan pemeriksaan fisik dan mental, dan Fase detoksifikasi dan terapi komplikasi medik, antara $1-3$ minggu 
untuk melakukan pengurangan ketergantungan bahan-bahan adiktif secara bertahap.

3.Tertier, yaitu upaya untuk merehabilitasi merekayang sudah memakai dan dalam proses penyembuhan. Tahap ini biasanya terdiri atas Fase stabilisasi, antara 3-12 bulan, untuk mempersiapkan pengguna kembali ke masyarakat, dan Fase sosialiasi dalam masyarakat, agar mantan penyalahguna narkoba mampu mengembangkan kehidupan yang bermakna di masyarakat. Tahap ini biasanya berupa kegiatan konseling, membuat kelompokkelompok dukungan, mengembangkan kegiatan alternatif, dll.

Adapun solusi alternatif yang dapat dilakukan oleh masyarakat (Non pemerintah)dalam mengatasi masalah narkoba ini, adalah dengan menggunakan beberapa pendekatanyang diterapkan kepada mereka, baik yang belum ataupun yang sudah terjerat belitan narkoba.

Beberapa pendekatan yang penulis maksud adalah sebagai berikut:

1.Pendekatan agama (religius). Melalui pendekatan ini, mereka yang masih 'bersih' dari dunia narkoba, senantiasa ditanamkan ajaran agama yang mereka anut. Agama apa pun, tidak ada yang menghendaki pemeluknya untuk merusak dirinya, masa depannya, serta kehidupannya. Setiap agama mengajarkan pemeluknya untuk menegakkan kebaikan, menghindari kerusakan, baik pada dirinya, keluarganya, maupun lingkungan sekitarnya.Sedangkan bagi merekayang sudah terlanjur masuk dalam kubangan narkoba, hendaknya diingatkan kembali nilai-nilai yang terkandung di dalam ajaran agama yang mereka yakini.Dengan jalan demikian, diharapkan ajaran agama yang pernah tertanam dalam benak mereka mampu menggugah jiwa mereka untuk kembali ke jalan yang benar.

2.Pendekatan psikologis. Dengan pendekatan ini, mereka yang belum terjamah 'kenikmatan semu' narkoba, diberikan nasihat dari 'hati ke hati' oleh orang-orang yang dekat dengannya, sesuai dengan karakter kepribadian mereka. Langkah persuasif melalui pendekatan psikologis ini diharapkan mampu menanamkan kesadaran dari dalam hati mereka untuk menjauhi dunia narkoba. Adapun bagi merekayang telah larut dalam 'kehidupan gelap' narkoba, melalui pendekatan ini dapat diketahui, apakah mereka masuk dalam kategori pribadiyang ekstrovert (terbuka), introvert (tertutup), atau sensitif. Dengan mengetahui latar belakang kepribadian mereka, maka pendekatan ini diharapkan mampu mengembalikan mereka pada kehidupan nyata, menyusun kembali kepingan perjalanan hidupyang sebelumnya berserakan, sehingga menjadi utuh kembali.

3.Pendekatan sosial. Baik bagi mereka yang belum, maupun yang sudah masuk dalam 'sisi kelam' narkoba, melalui pendekatan ini disadarkan bahwa mereka merupakan bagian penting dalam keluarga dan lingkungannya. Dengan penanaman sikap seperti ini, maka mereka merasa bahwa kehadiran mereka di tengah keluarga dan masyarakat memiliki arti penting. Dengan beberapa pendekatan di atas, diharapkan mampu menggerakkan hati para remaja dan generasi mudayang masih 'suci' dari kelamnya dunia narkoba untuk tidak larut dalam trend pergaulan yang menyesatkan. Dan bagi mereka yang sudah tercebur ke dalam 'kubangan' dunia narkoba, melalui beberapa pendekatan tersebut, diharapkan dapat kembali sadar akan arti 
penting kehidupan ini, yang amat sayang jika digadaikan dengan kesenangan yang nisbi.

Dengan demikian, jika pemerintah dan masyarakat menjalankan fungsi dan perannya dengan baik, niscaya upaya memerangi narkoba serta menyelamatkan bangsa Indonesia dari "bahaya mematikan" narkoba akan menemui titik terang.

\section{KESIMPULAN DAN SARAN Kesimpulan.}

1. Narkoba adalah bahan/zat yang jika dimasukan dalam tubuh manusia, baik secara oral/diminum, dihirup, maupun disuntik, dapat mengubah pikiran, suasan hati atau perasaan,dan perilaku seorang..

2. narkoba dapat menimbulkan ketergantungan (Adiksi) fisik dan fisiologis.jadi sebaiknya kita harus menghindari yang dikatakan "NARKOBA"

3. Narkoba dapak menimbulkan berbagai dampak bagi kehidupan manusia. Diantaranya adalah Dampak fisik, emosi, perilaku, psikis, dan social

\section{Saran}

1. Diharapkan sebagai remaja dan pelajar hendaknya mampu menjauhkan diri dari segala sesuatu yang berhubungan dengan narkoba untuk menjaga masa depan kita yang begitu berharga.

2. Diharapkan para orang tua senantiasa menjaga dan melindundi anak-anak mereka dari bahaya obat-obatan haram ini, mengingat anak adalah aset yang sangat berharga dan merupakan anugerah yang sangat indah dari Tuhan Yang Maha Kuasa
3. Semoga makalah yang singkat ini mampu memberi manfaat bagi kita semua baik dari kalangan mahasiswa dan pelajar umum, sehingga bisa memahami bahaya narkoba yang dapat menggrogoti moral kita. Dan sebagai generasi muda maka kita harus menyadari bahwa kita adalah tulang punggung bangsa sekaligus bertanggung jawab atas kemajuan dan masa depan bangsa serta tanah air tercinta Indonesia.

\section{DAFTAR PUSTAKA}

Ahmad Amin, Bahaya Narkoba, Bandung, Remaja Rosdakarya, 1991

Effendi, Luqman, Modul Dasar-

Dasar Sosiologi \& Sosiologi Kesehatan

I. Jakarta: PSKM FKK UMJ, 2008

Kartono, Kartini, Patologi II

Kenakalan Remaja. Jakarta:

Rajawali.1992

Mangku, Made Pastika, Mudji

Waluyo, Arief Sumarwoto, dan Ulani Yunus, Pencegahan Narkoba Sejak Usia Dini. Jakarta: Badan Narkotika Nasional Republik Indonesia.2007

Shadily, Hassan, Sosiologi Untuk Masyarakat Indonesia. Jakarta: PT RINEKA CIPTA.1993

Soekanto, Suryono, Sosiologi Suatu Pengantar. Jakarta: PT Raja Grafindo Persuda,2006

Sofyan, Ahmadi, Narkoba Mengincar Anak Anda Panduan bagi Orang tua, Guru, dan Badan Narkotika dalam Penanggulangan Bahaya Narkoba di Kalangan Remaja. Jakarta: Prestasi Pustaka Publisher.2007

Sudarman, Momon, Sosiologi Untuk Kesehatan. Jakarta: Salemba Medika.2008

Syani, Abdul, Sosiologi dan Perubahan Masyarakat. PT Dunia Pustaka Jaya.1995 